\title{
A STUDY ON MECHANICAL CHARACTERIZATION OF ALUMINIUM METAL MATRIX COMPOSITE REINFORCED WITH ALOE VERA POWDER
}

\author{
RAGHUNANDAN M' ${ }^{1}$, TEJAS $P^{2}$, TULASI PRASAD $C^{3}$, \\ RUDRAPADA BHARAT KUMAR ${ }^{4}$
}

Student, Mechanical Engineering, K S Institute of Technology, Bengaluru, India ${ }^{1-4}$

\begin{abstract}
In recent years, metal matrix composites (MMCs) attracted researchers more as they become one of the most important structural materials depending on the requirement. Specifically, the particulate reinforced aluminium metal matrix composites have received significant attention due to the improved mechanical and tribological properties such as strength, stiffness, impact resistance, wear resistance etc. The ceramic particles such as silicon carbide and aluminium oxide are the most widely used for reinforcement of aluminium matrix.

In recent times, the growing concern of manufacturing industries is to use cost-effective reinforced Aluminium metal matrix composites for meeting their production rates with the least cost considerations without sacrificing the specific properties. In this context, several attempts were made by the researchers to use various materials such as graphite, red mud, bagasse ash, rice husk ash, fly ash etc. for reinforcement of the Aluminium metal matrix. An attempt has been made to employ Aloe vera powder as a reinforcement material for Aluminium metal matrix composites as it is readily available less dense eco-friendly material at low cost and it could be the alternative to other materials in respect of better physical and mechanical properties. In the present work stir casting method is employed for preparing the specimens of Aluminium matrix composite with aloe vera reinforcement. An experimental study has been carried out on the mechanical characterization of aluminium metal matrix composites using aloe vera as reinforcement material. The findings of the experimental investigation reveal that there is a significant improvement in mechanical properties such as hardness, tensile strength when aloe vera is used as reinforcement material.
\end{abstract}

\section{INTRODUCTION}

Nowadays metal matrix composites (MMCs) are more attractive for manufacturing industries as they are the replacement for conventional materials in many engineering applications. In general MMCs consist of at least two components, one is the metal matrix (pure metal or alloy) and the other is the reinforcement material. The addition of reinforcement material into the metal matrix improves the specific strength, stiffness, wear, creep and fatigue compared to the conventional engineering materials.

Based on reinforcement materials, there are four kinds of MMCs namely:

-

Particle-reinforced MMCs (Particulate MMCs):

(a)

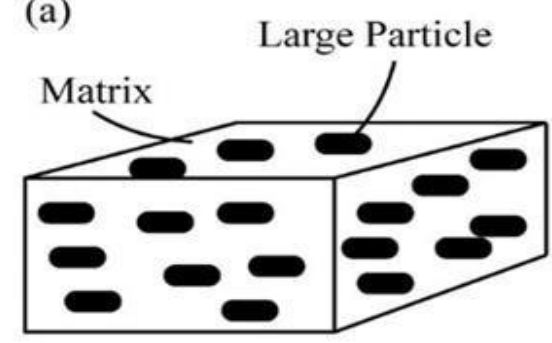

(b)

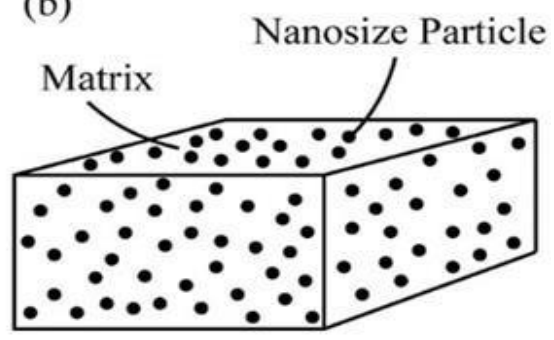

Types of particle -reinforced composites (a) Large -particle (b) Dispersion -strengthened

Particle composites consist of particles of one material dispersed in a matrix of a second material. Particles may have any shape or size but are generally spherical, ellipsoidal, polyhedral, or irregular in shape. 


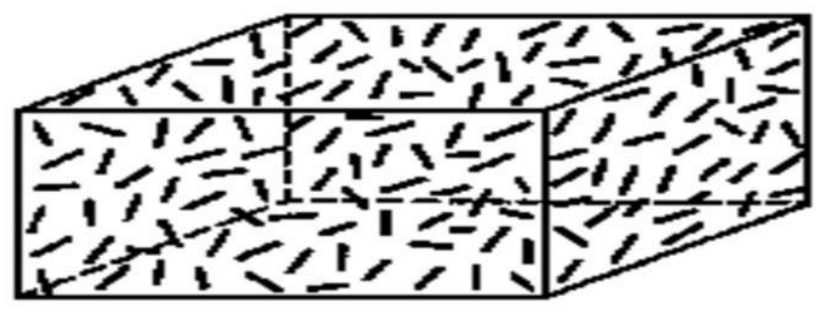

Mechanical properties of short fibre reinforced composites depend critically on the fibre length distribution (FLD) and the fibre orientation distribution. In particular, the strength of short fibre reinforced composites increases with the increase of the mean fibre length and with the decrease of the mean fibre orientation angle (angle between the fibre axis and the loading direction).

Continuous fibre (sheet) - Reinforced MMCs:

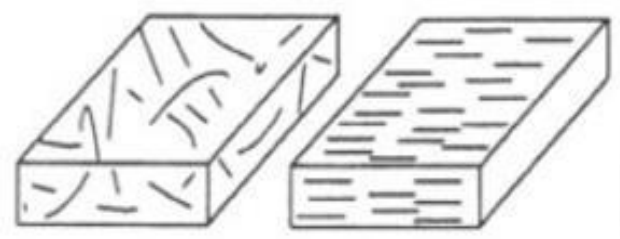

Random fiber orientation
Biased fiber orientation

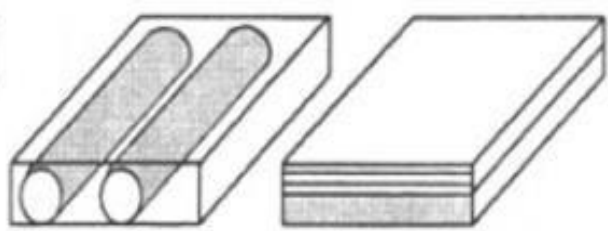

Unidirectional
Laminated

Discontinuous fiber composites

Continuous fibre reinforcement provides the most effective strengthening (in a given direction), particle reinforced materials are more attractive due to their cost-effectiveness, isotropic properties, and their ability to be processed using similar technology used for monolithic materials.
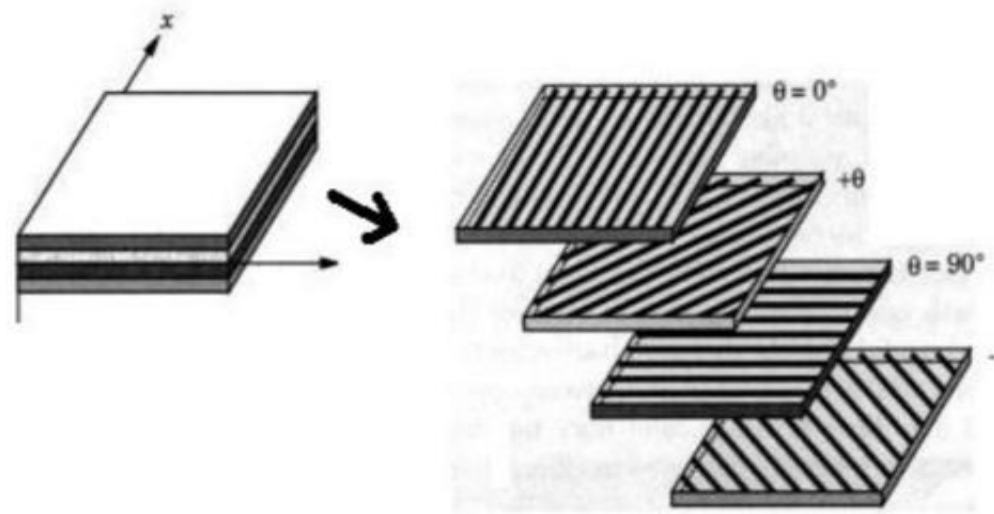

In material science, a composite laminate is an assembly of layers of fibrous composite materials that can be joined to provide required engineering properties, including in-plane stiffness, bending stiffness, strength, and coefficient of thermal expansion.

Earlier studies reveal that the application of continuous fibre reinforced MMCs have been hindered by high manufacturing costs associated with the high costs of the reinforcement fibres and highly labour-intensive manufacturing processes. Consequently, utilization of these materials has been limited to military and other highly specialized applications.

Even though whisker reinforced MMCs have been shown to have good combinations of strength and thermal stability relative to those of particulate reinforced materials, the commercialization of whisker reinforced MMCs has been slow as a result of high costs associated with currently available whiskers, faulted internal structure of whiskers etc.

The particulate MMCs have recently been used in various engineering applications because of the ease of formability and 


\section{International Advanced Research Journal in Science, Engineering and Technology \\ Impact Factor $7.105 \div$ Vol. 9, Issue 1, January 2022 \\ DOI: 10.17148/IARJSET.2022.9162}

relatively modest cost. Explicitly the Particulate Aluminium Matrix Composites (PAMCs) have been successfully used as components in automotive, aerospace, optomechanical assemblies, braking systems of trains and cars, gas turbine engines, helicopters, military aircraft, etc.

Based on reinforcing materials, the PAMCs are classified into three broad categories namely

- $\quad$ Synthetic ceramic particulates

- $\quad$ Industrial wastes

- $\quad$ Agro waste derivatives

The development of AMCs reinforced with agro and industrial waste derivatives have a lot of focus in the present day manufacturing scenario to achieve the benefits of significant processing cost reduction, satisfactory physical and mechanical properties.

Some of the studies were made to investigate the properties of AMCs reinforced with various industrial wastes (byproducts) and agro derivatives. They observed that the increase in fly ash content increases the wear resistance of the composite and there is a decrease in corrosion resistance.

More recently the focus of researchers turns towards the use of agro derivatives as reinforcement materials in aluminium metal matrix composites to complement reinforcement to either silicon carbide or alumina. A few agro derivatives such as breadfruit seed hull, rice husk, bamboo leaf, coconut shell, sugarcane bagasse etc. have been processed into ashes and their suitability for use as reinforcing material has been studied.

In this context, it is necessary to identify eco-friendly reinforcement materials for producing aluminium metal matrix composites. In the present work, aloe vera powder is considered a novel reinforcement material for AMCs.

\section{Aloe Vera Powder:}

Aloe vera is a perennial, drought-resisting, succulent plant belonging to the Asphodelaceae family. The name Aloe vera is derived from the Arabic word Aloeh and the Latin word vera means shining bitter substance and true respectively. Aloe Vera (Aloe barbadensis miller) is a tropical or sub-tropical plant that has lance-shaped leaves with jagged edges and sharp points.

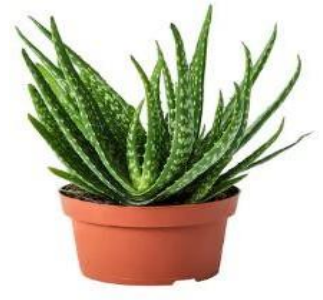

Fig: Aloe vera plant

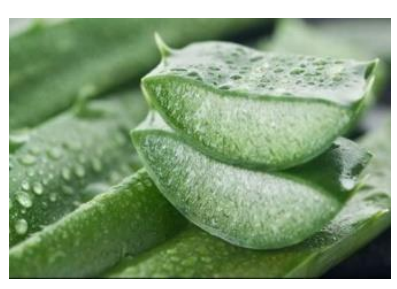

Fig: Aloe vera leaf

This plant is being used extensively for medicinal purposes and the cosmetic industry. It was originated in tropical Africa and it is now cultivated in warm climatic areas of Asia, Europe and America. In India, Rajasthan, Andhra Pradesh, Chhattisgarh, Gujarat, Tamil Nadu, Maharashtra and Kerala are the major producers of this crop.

The cultivation of aloe vera plants is economically very attractive. The plantation of aloe vera does not require much water and it requires $150 \mathrm{ml}$ of water monthly for the yield of good quality leaf weighing approximately $1 \mathrm{~kg}$.

In India, the average yield for organically grown aloe is about 12 tonnes per hectare. The aloe Vera has a higher water holding capacity and essentially contains calcium (3.58\%), magnesium (1.22\%), sodium (3.66\%), potassium (4.06\%), Phosphorous $(0.02 \%)$, iron $(0.1 \%)$, copper $(0.06 \%)$ and zinc $(0.02 \%)$.

The contact angle for aloe Vera leaves is $96.89^{\circ}$ and hence it possesses significant wettability. It is a cactus-like plant with green, dagger-shaped leaves that are fleshy, tapering, spiny, marginated and filled with a clear viscous gel.

As aloe vera is a largely available, easily cultivable, less dense eco-friendly material with considerable wettability, it is suitable for reinforcement of AMCs.

It is observed from the literature that less work has been reported on the use of aloe Vera as reinforced material pure aluminium (grade 1060; $99.6 \%$ purity) with density $2.7 \mathrm{~g} / \mathrm{cc}$ is used as matrix material.

To prepare a set of AMC specimens, aloe vera powder is employed in the present investigation. In this paper, an attempt is made to prepare aloe vera (AV) reinforced aluminium metal matrix composite and to examine its mechanical characterization. 
International Advanced Research Journal in Science, Engineering and Technology

Impact Factor 7.105 Vol. 9, Issue 1, January 2022

DOI: 10.17148/IARJSET.2022.9162

\section{OBJECTIVES AND PROBLEM DEFINITION}

Objectives:

- Toenhance the mechanical properties of pure aluminium (99\% pure) by reinforcing it with aloe vera powder.

- To investigate the mechanical behaviour of the casted specimen by subjecting it through various tests (tensile, hardness, wear etc.)

- $\quad$ To determine the fatigue strength of the casted specimen along with microstructure.

\section{Problem Definition:}

- The present work is selected to study the behaviour of the aluminium and aloe vera composite material. The primary motive is to conduct experimental evaluations on the proposed composite material.

\section{Material Selection:}

The material selection for the experimentation is aluminium 1060 with considering purity factor. The alloy composition of 1060 aluminium is:

- Aluminium: $99.6 \% \mathrm{~min}$

- Copper: $0.05 \% \max$

- Iron: $0.35 \% \max$

- $\quad$ Magnesium: $0.03 \% \max$

- $\quad$ Manganese: $0.03 \% \max$

- Silicon: $0.25 \% \max$

- Titanium: $0.03 \% \max$

- Vanadium: $0.05 \% \max$

- Zinc: $0.05 \% \max$

In the present work, the commercially available pure aluminium grade 1060(99.6\% purity) with adensity of $2.7 \mathrm{~g} / \mathrm{cc}$ was used as a matrix material. To prepare a few sets of AMC specimen AV powder were employed in the present investigation.

\section{METHODOLOGY}

Step by step methodology followed:

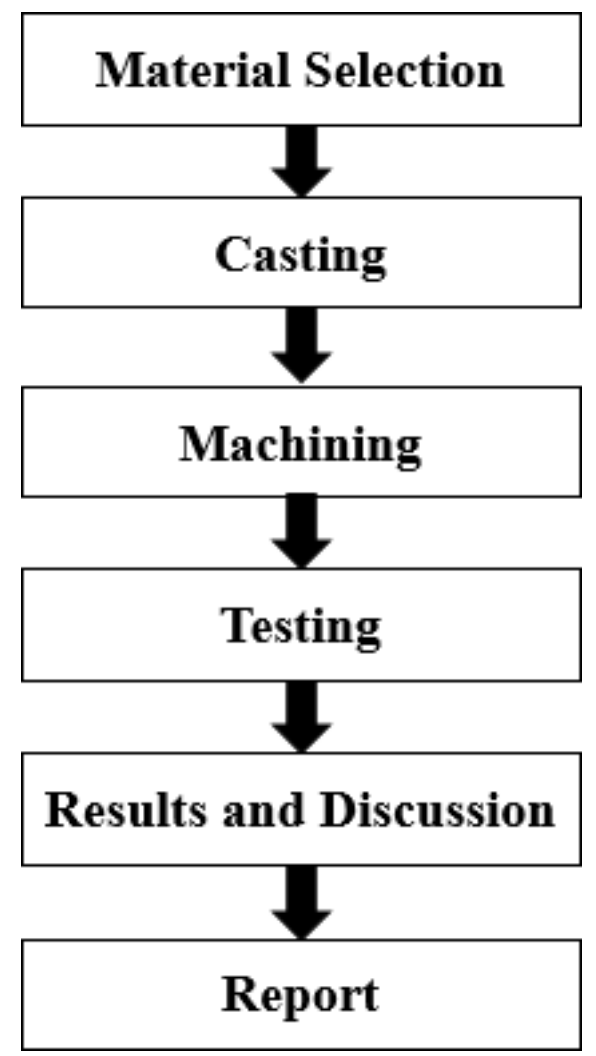




\section{International Advanced Research Journal in Science, Engineering and Technology \\ Impact Factor $7.105 \div$ Vol. 9, Issue 1, January 2022 \\ DOI: $10.17148 / I A R J S E T .2022 .9162$}

\section{Methodology Procedure:}

The stir casting method has been employed for preparing the two different sets of AMCs with reinforcement materials AV powder. While fabricating the AMCs reinforced with AV powder, the preparation for the base metal matrix is similar to that of the fabrication of AMC-FA. After that, the AV powder of 3\%, 6\%, $9 \%$ and $12 \%$ wt. of base metal was introduced slowly into the molten aluminium which is at about $720^{\circ} \mathrm{C}$. To improve the wettability of AV powder, magnesium (10gms) was added and then the molten metal was stirred at a constant speed of $300 \mathrm{rpm}$ for 5 minutes to attain homogeneity of the mixture of matrix material and AV powder. The melt was poured into the mild steel die after the mixture was kept in the crucible forabout half a minute in static condition and then it was poured and cast in mild steel die.

\section{Casting Procedure:}

1) At first, the crucible was thoroughly cleaned before the material was added.

2) The temperature of the furnace was set to $800^{\circ} \mathrm{C}$.

3) Then $2 \mathrm{kgs}$ of Al was weighed on a weighing machine and was then allowed to melt inside the crucible.

4) Then the reinforcement materials were added to the crucible (magnesium and aloe vera powder) and were stirred continuously for 10 minutes at $300 \mathrm{rpm}$.

5) Degasser tablets were added to remove the gas present in the molten metal.

6) Scum powder was added to remove the slag and flux.

7) Before pouring the molten metal the mould was thoroughly heated by a gas heater.

\section{Machining:}

Then a set of AMCs which are reinforced with AV powder are obtained

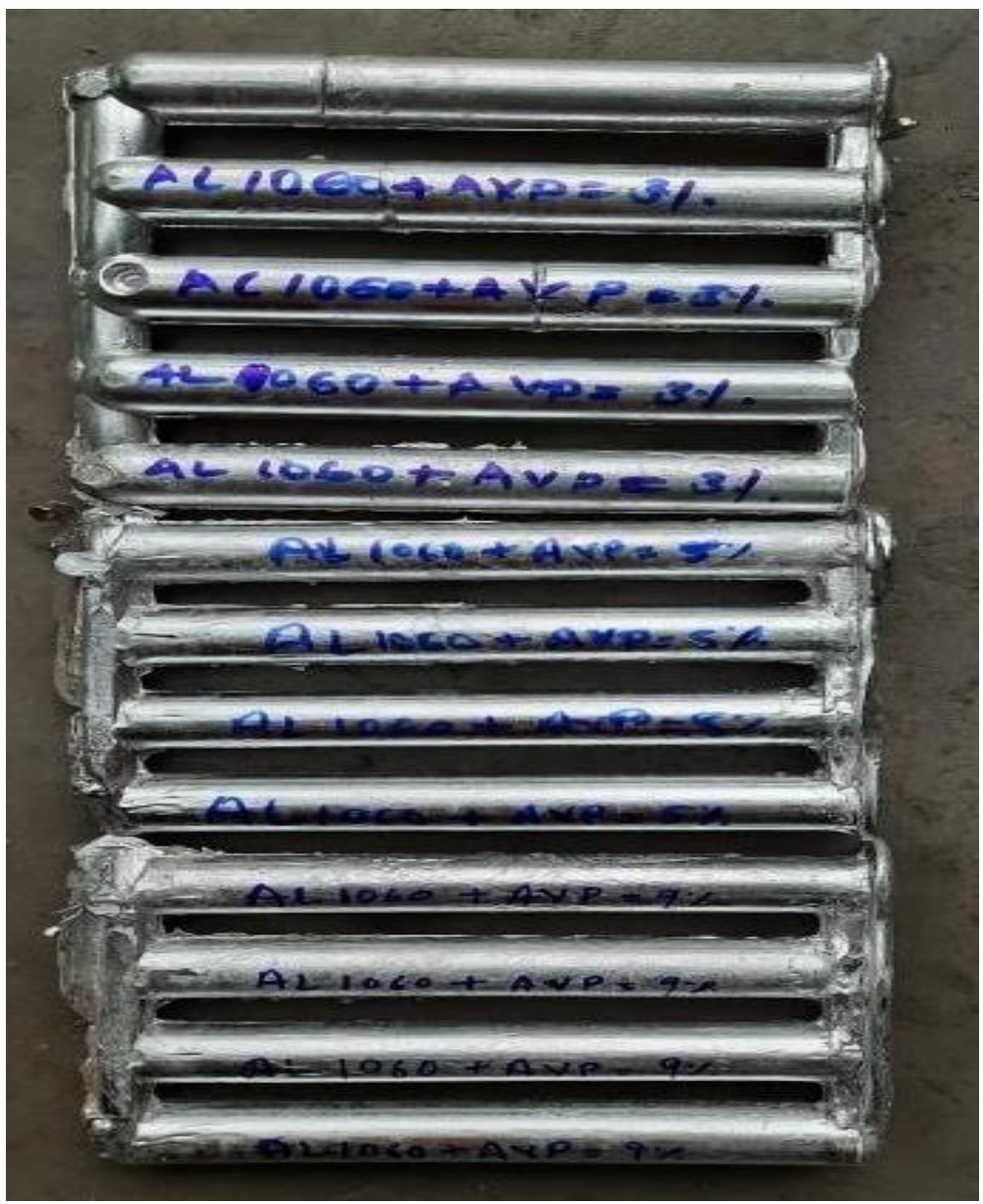

Fig: Casted Specimens 


\section{International Advanced Research Journal in Science, Engineering and Technology}

Impact Factor $7.105 \div$ Vol. 9, Issue 1, January 2022

DOI: 10.17148/IARJSET.2022.9162

The obtained AMCs were then machined as per ASTM standards by the tests they were subjected to.

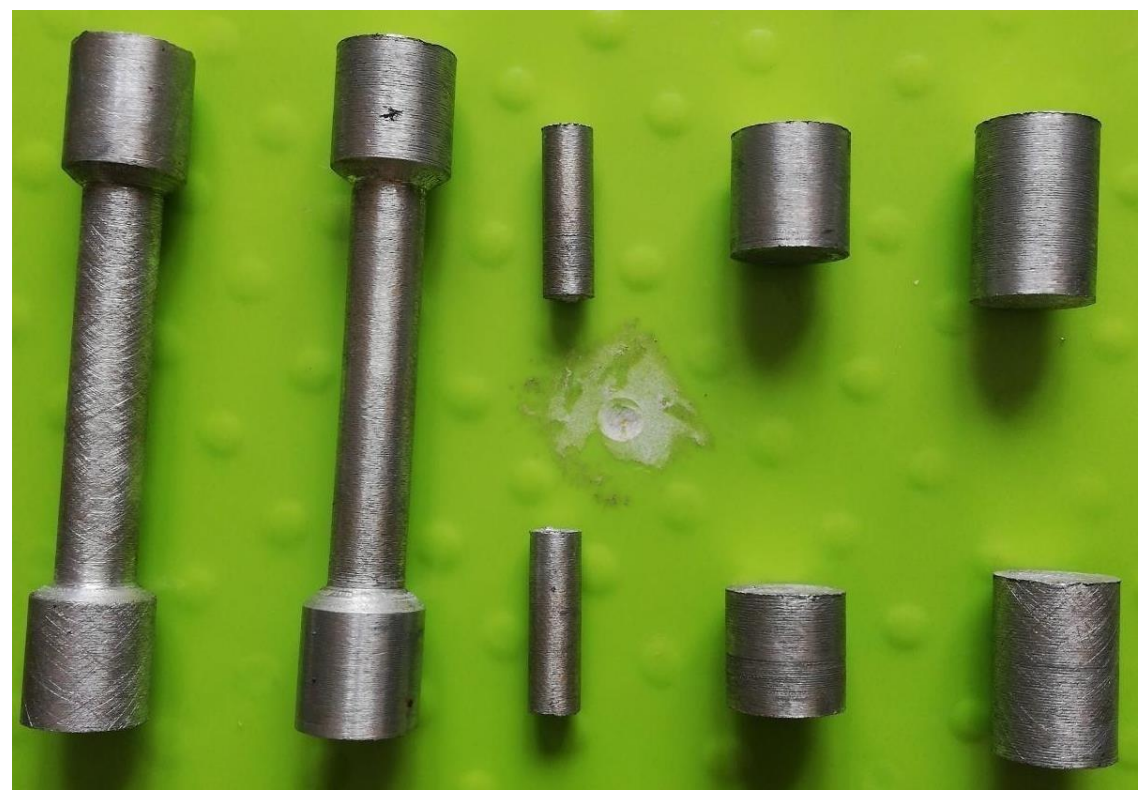

Fig: Specimens machined according to ASTM standards

Testing:

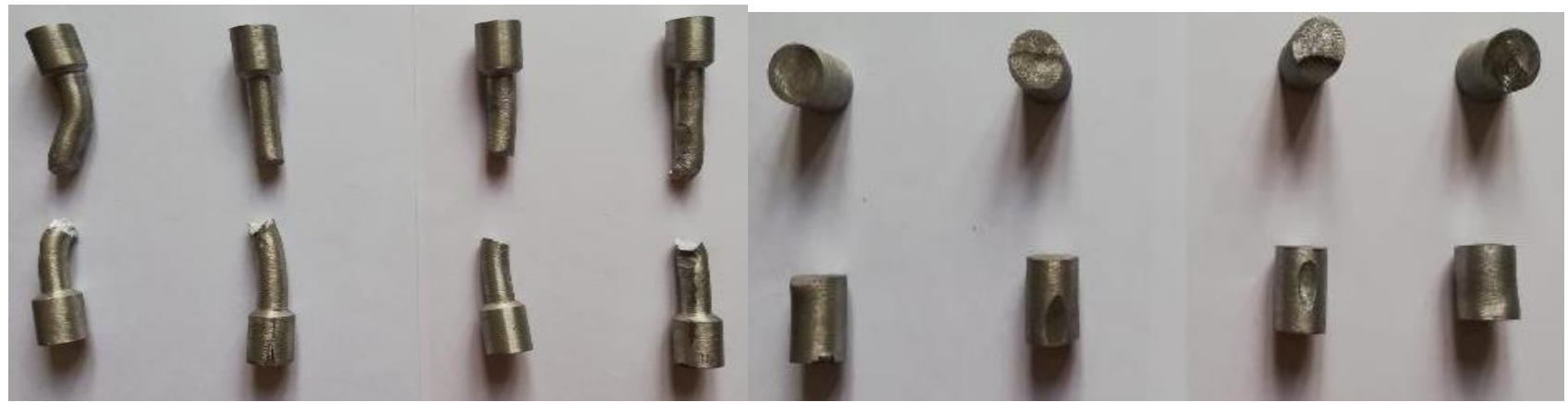

Fig: Tensile tested specimen

Fig: Compression tested specimen

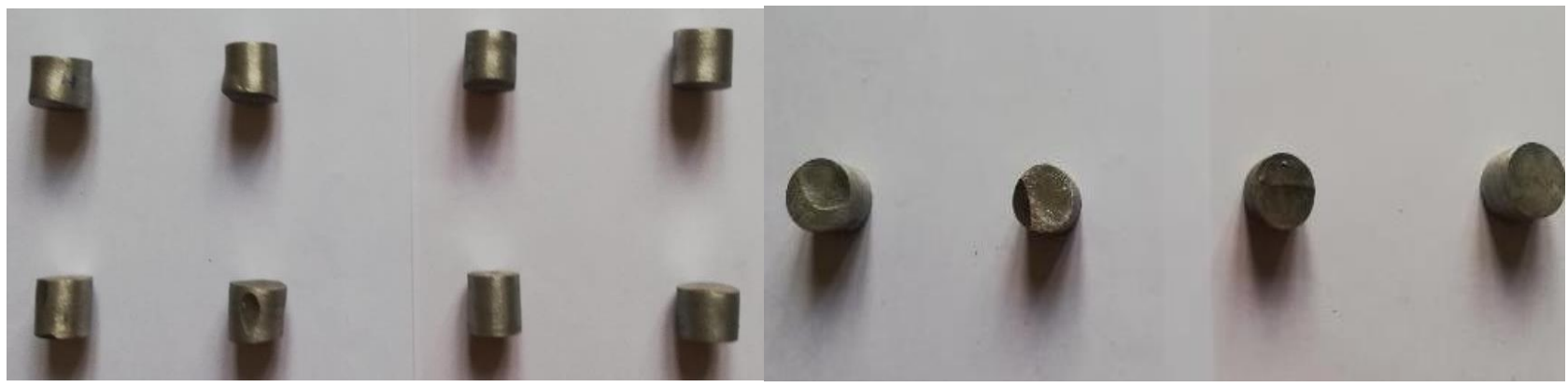

Fig: Brinell Hardness tested specimen

Fig: Microstructure Analysis tested specimen 
International Advanced Research Journal in Science, Engineering and Technology

Impact Factor 7.105 Vol. 9, Issue 1, January 2022

DOI: 10.17148/IARJSET.2022.9162

RESULTS AND DISCUSSION

Aluminium Composite for 3\%

Tensile Test Result:

Test Method: ASTM E8M-15a

\begin{tabular}{|c|c|}
\hline \multicolumn{2}{|c|}{ TEST RESULTS } \\
\hline Initial Area $\left(\mathrm{mm}^{2}\right)$ & 64.57 \\
\hline Initial Gauge Length $(\mathrm{mm})$ & 45.00 \\
\hline Final Gauge Length $(\mathrm{mm})$ & 51.47 \\
\hline Yield Strength $(\mathrm{MPa})$ & 168.30 \\
\hline Ultimate Tensile Load $(\mathrm{kN})$ & 12.86 \\
\hline Ultimate Tensile Strength $(\mathrm{MPa})$ & 199.30 \\
\hline \% Elongation & 14.37 \\
\hline
\end{tabular}

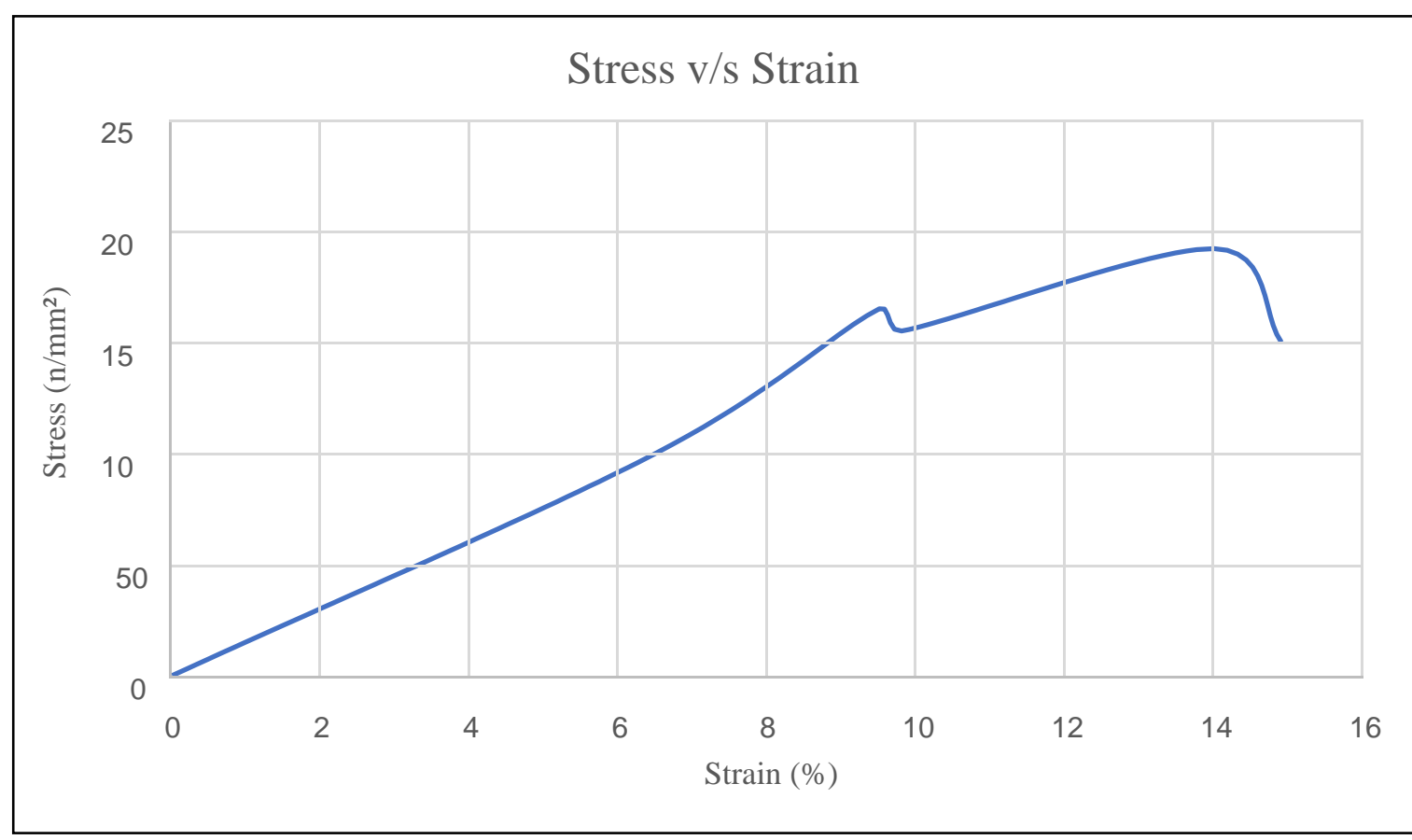

BHN Hardness Test:

Test Method: IS 1500-2010 Ball Dia: 5mm

Load $250 \mathrm{Kg}$

\begin{tabular}{|l|l|l|l|l|}
\hline Sample & Result-1 & Result-2 & Result-3 & Average \\
\hline 01 & 77.3 & 75.2 & 76.5 & 76.33 \\
\hline
\end{tabular}


International Advanced Research Journal in Science, Engineering and Technology

Impact Factor 7.105 ㄷ Vol. 9, Issue 1, January 2022

DOI: 10.17148/IARJSET.2022.9162

Compression Test:

\begin{tabular}{|l|l|l|l|l|}
\hline Sample & Dia $(\mathrm{mm})$ & Area $\left(\mathrm{mm}^{2}\right)$ & Compression Load $(\mathrm{KN})$ & Compression Strength $(\mathrm{MPa})$ \\
\hline 01 & 20.00 & 314.2 & 80.06 & 247.07 \\
\hline
\end{tabular}

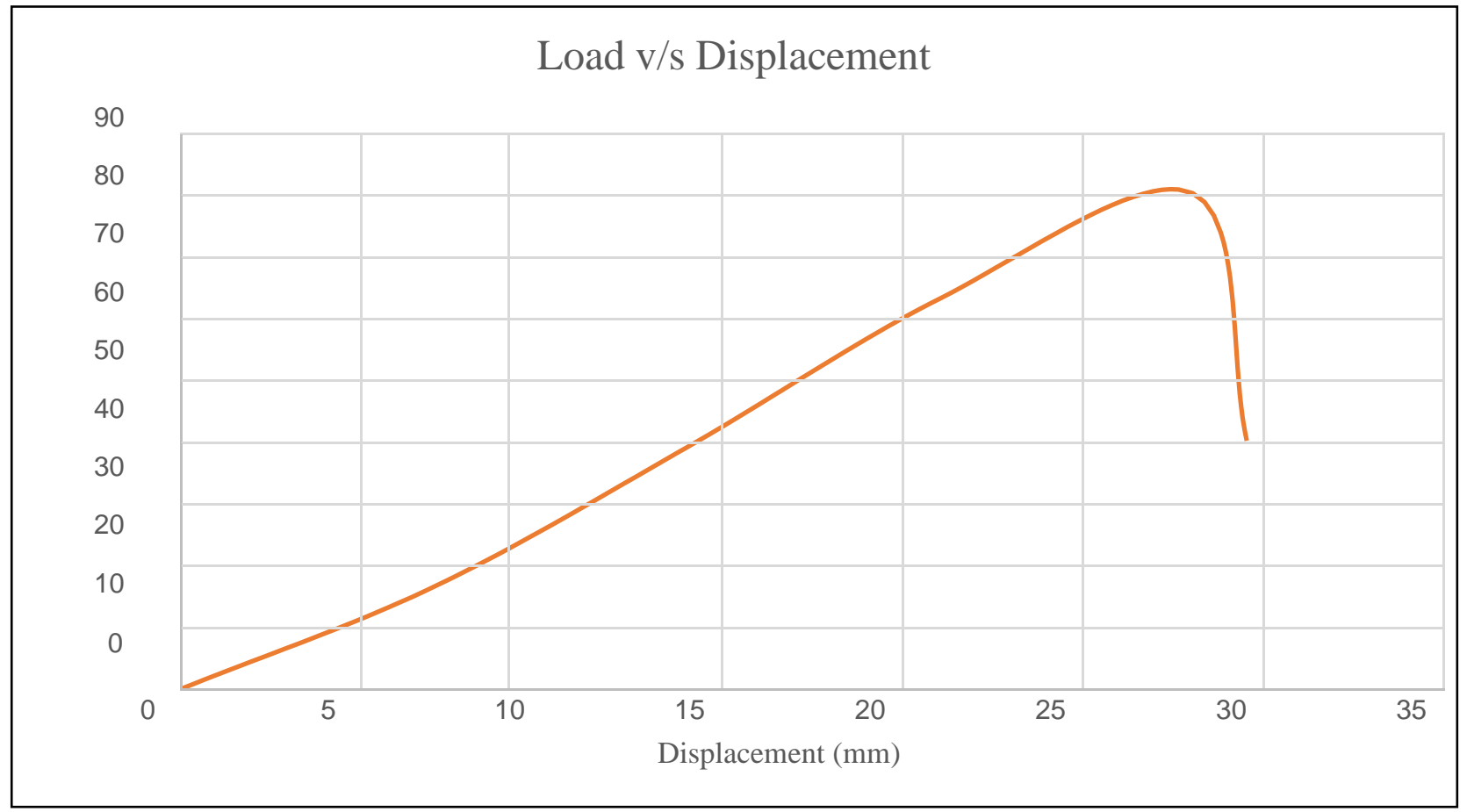

Microstructure Analysis:

Test Method: ASTM A356-19

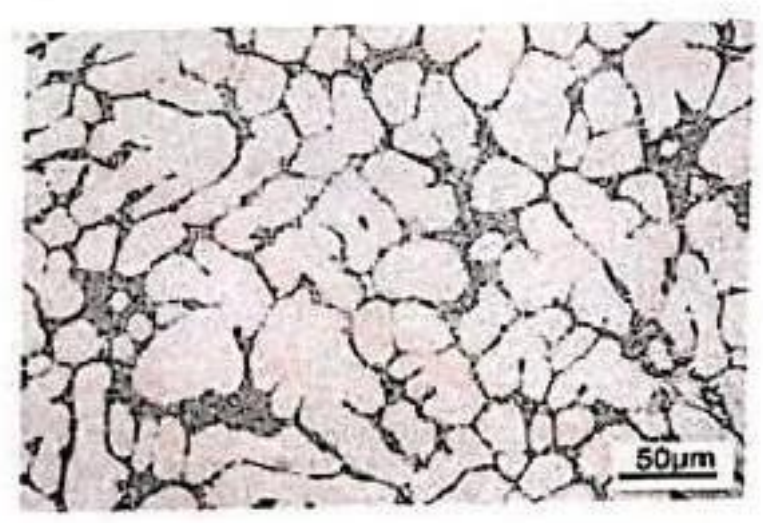

Remark:

The Solidification of alloy continues with the formation of Al-Si eutectic mixture

Aluminium Composite for $6 \%$

Tensile Test Result:

Test Method: ASTM E8M-15a 
International Advanced Research Journal in Science, Engineering and Technology

Impact Factor 7.105 ㄷ Vol. 9, Issue 1, January 2022

DOI: 10.17148/IARJSET.2022.9162

\begin{tabular}{|c|c|}
\hline \multicolumn{2}{|c|}{ TEST RESULTS } \\
\hline Initial Area $\left(\mathrm{mm}^{2}\right)$ & 65.34 \\
\hline Initial Gauge Length $(\mathrm{mm})$ & 45.00 \\
\hline Final Gauge Length $(\mathrm{mm})$ & 51.17 \\
\hline Yield Strength $(\mathrm{MPa})$ & 191.40 \\
\hline Ultimate Tensile Load $(\mathrm{kN})$ & 14.72 \\
\hline Ultimate Tensile Strength $(\mathrm{MPa})$ & 225.30 \\
\hline$\%$ Elongation & 13.71 \\
\hline
\end{tabular}

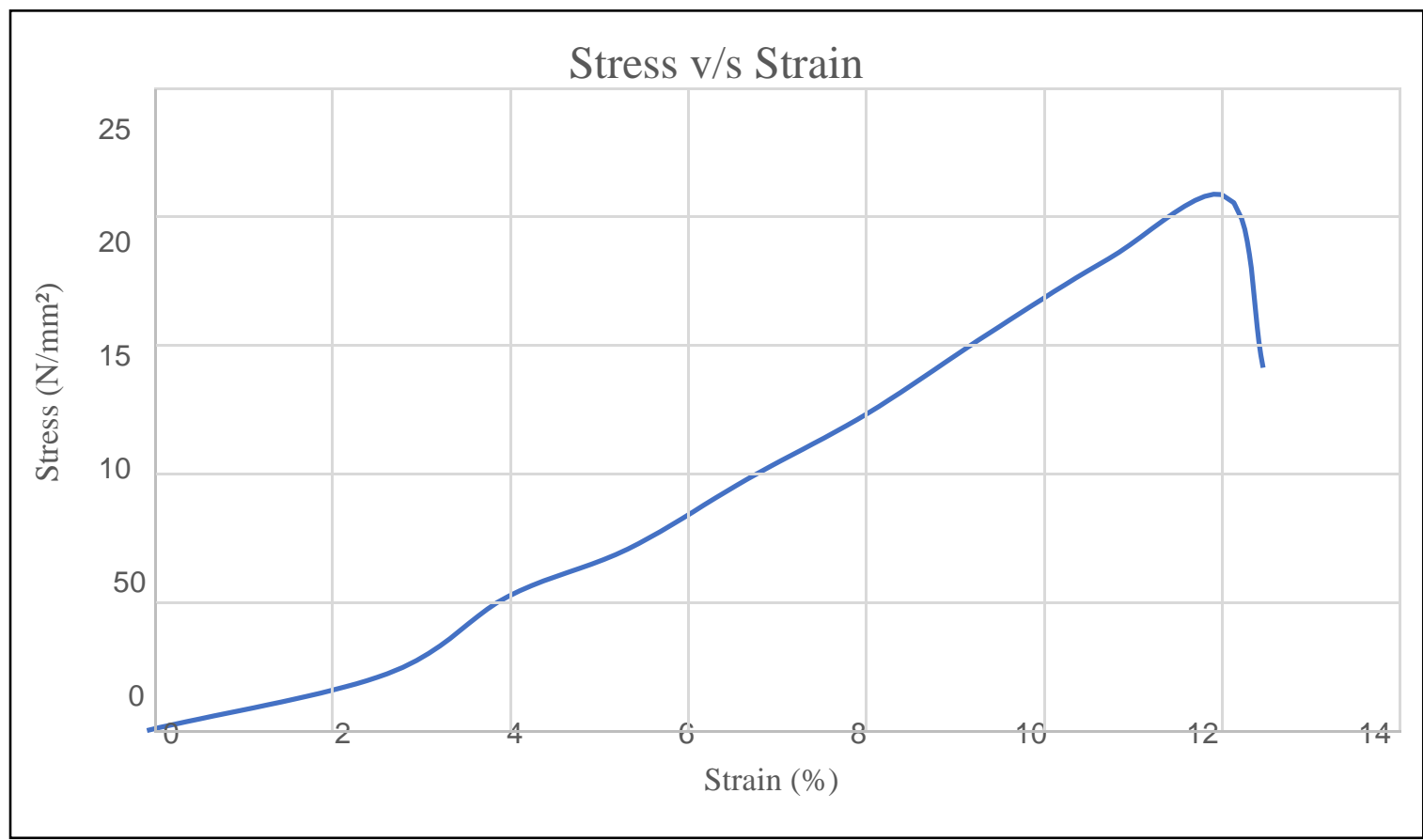

BHN Hardness Test:

Test Method: IS 1500-2010 Ball Dia: 5mm

Load $250 \mathrm{Kg}$

\begin{tabular}{|l|l|l|l|l|}
\hline Sample & Result-1 & Result-2 & Result-3 & Average \\
\hline 01 & 190.3 & 191.2 & 192.6 & 191.36 \\
\hline
\end{tabular}

Compression Test:

\begin{tabular}{|l|l|l|l|l|}
\hline Sample & Dia $(\mathrm{mm})$ & Area $\left(\mathrm{mm}^{2}\right)$ & Compression Load $(\mathrm{KN})$ & Compression Strength $(\mathrm{MPa})$ \\
\hline 01 & 20.00 & 314.2 & 81.96 & 260.78 \\
\hline
\end{tabular}


International Advanced Research Journal in Science, Engineering and Technology

Impact Factor 7.105 ㄷ Vol. 9, Issue 1, January 2022

DOI: 10.17148/IARJSET.2022.9162

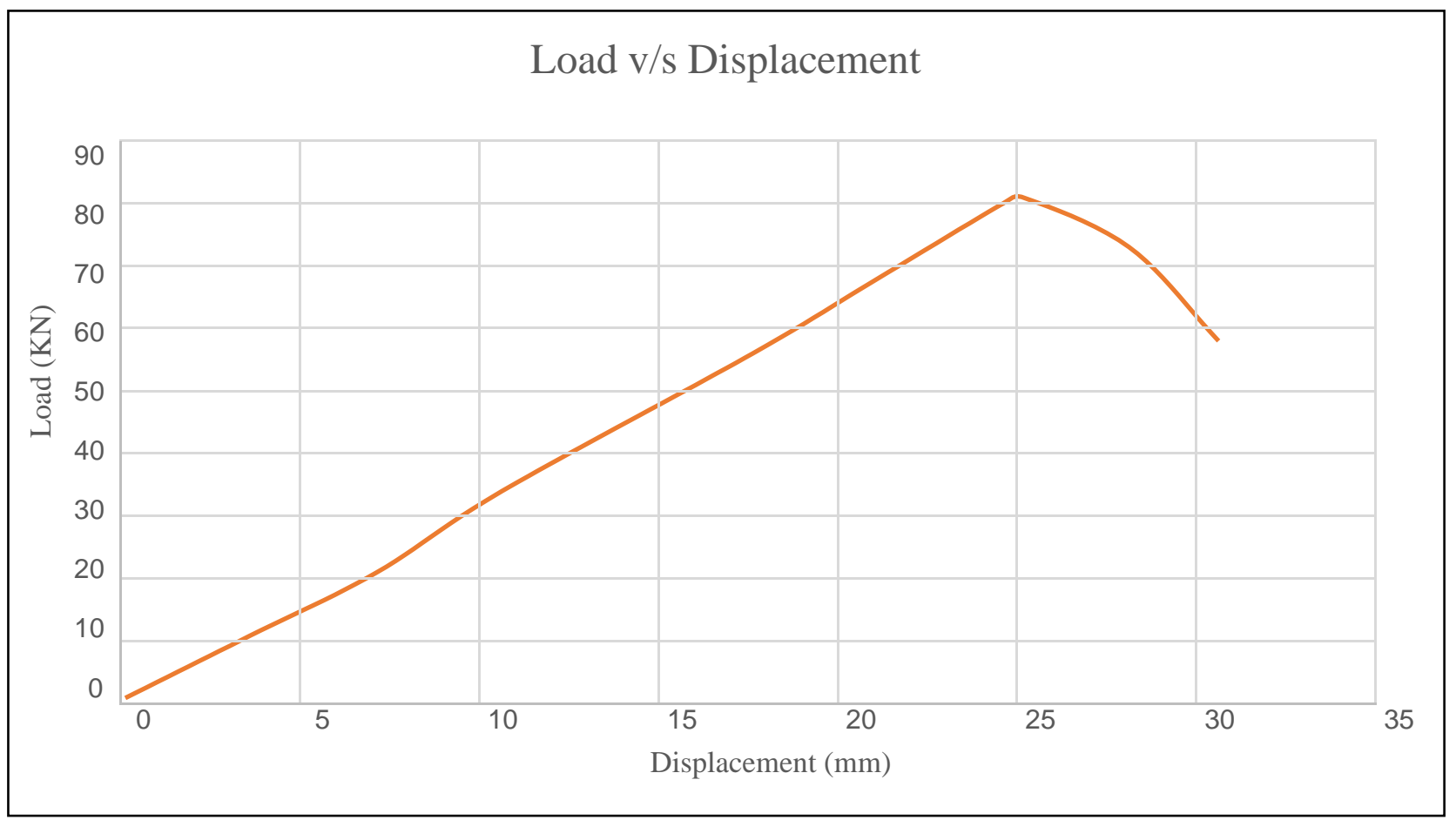

Microstructure Analysis:

Test Method: ASTM A356-19

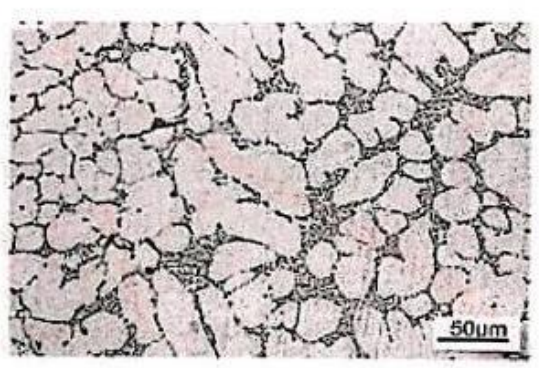

Remark:

The Solidification of alloy continues with the formation of Al-Si eutectic mixture

Aluminium Composite for 9\%

Tensile Test Result:

Test Method: ASTM E8M-15a

\begin{tabular}{|c|c|}
\hline \multicolumn{2}{|c|}{ TEST RESULTS } \\
\hline Initial Area $\left(\mathrm{mm}^{2}\right)$ & 66.17 \\
\hline Initial Gauge Length $(\mathrm{mm})$ & 45.00 \\
\hline Final Gauge Length $(\mathrm{mm})$ & 50.34 \\
\hline Yield Strength $(\mathrm{MPa})$ & 210.50 \\
\hline Ultimate Tensile Load $(\mathrm{kN})$ & 16.29 \\
\hline Ultimate Tensile Strength $(\mathrm{MPa})$ & 246.30 \\
\hline$\%$ Elongation & 11.86 \\
\hline
\end{tabular}


International Advanced Research Journal in Science, Engineering and Technology Impact Factor $7.105 \div$ Vol. 9, Issue 1, January 2022

DOI: 10.17148/IARJSET.2022.9162

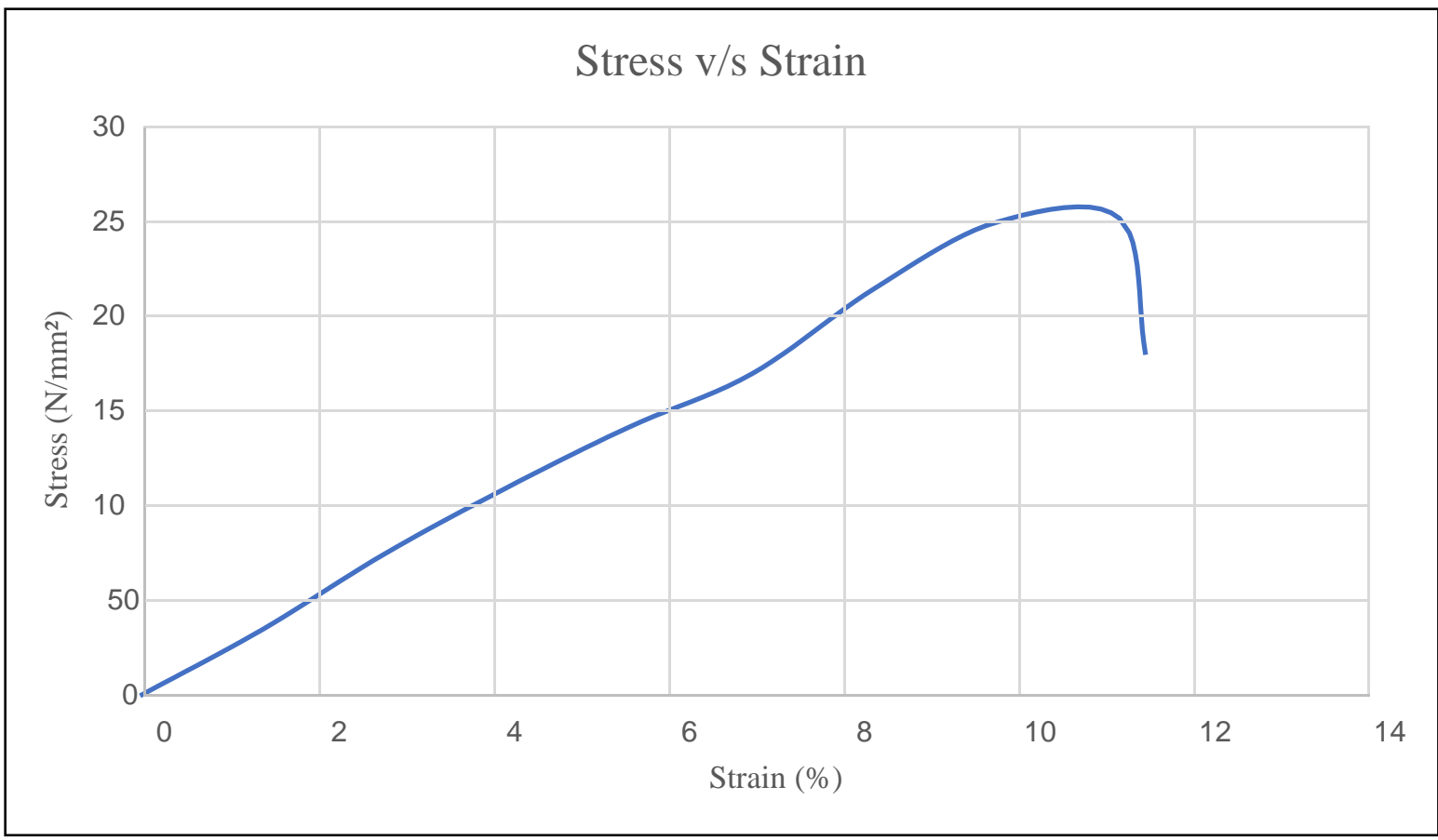

BHN Hardness Test:

Test Method: IS 1500-2010 Ball Dia: 5mm Load $250 \mathrm{Kg}$

\begin{tabular}{|l|l|l|l|l|}
\hline Sample & Result-1 & Result-2 & Result-3 & Average \\
\hline 01 & 103.2 & 103.9 & 102.6 & 103.23 \\
\hline
\end{tabular}

\section{Compression Test:}

\begin{tabular}{|l|l|l|l|l|}
\hline Sample & Dia $(\mathrm{mm})$ & Area $\left(\mathrm{mm}^{2}\right)$ & Compression Load $(\mathrm{KN})$ & Compression Strength $(\mathrm{MPa})$ \\
\hline 01 & 20.00 & 314.2 & 81.96 & 260.78 \\
\hline
\end{tabular}

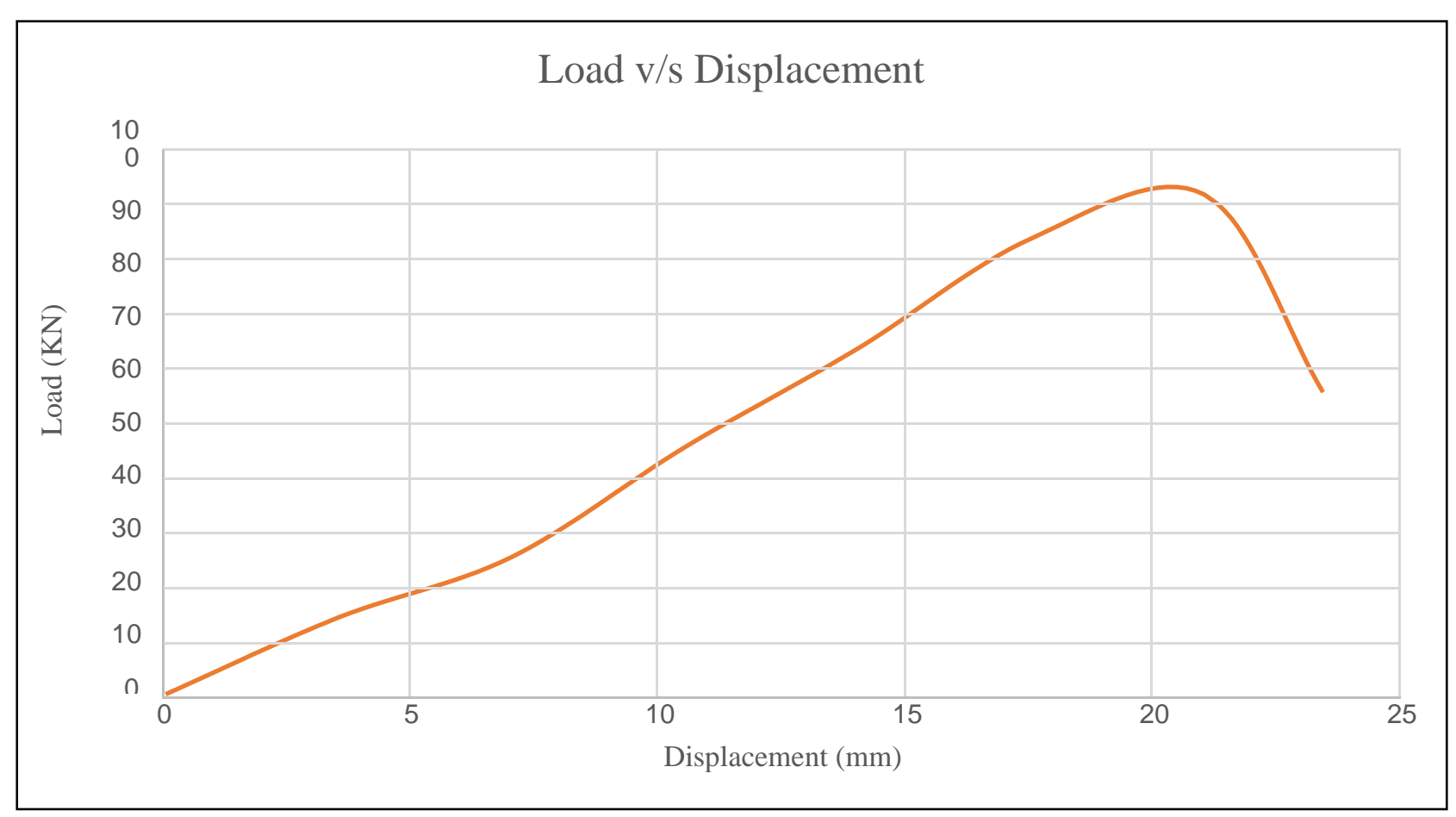


International Advanced Research Journal in Science, Engineering and Technology

Impact Factor 7.105 Vol. 9, Issue 1, January 2022

DOI: 10.17148/IARJSET.2022.9162

Microstructure Analysis:

Test Method: ASTM A356-19

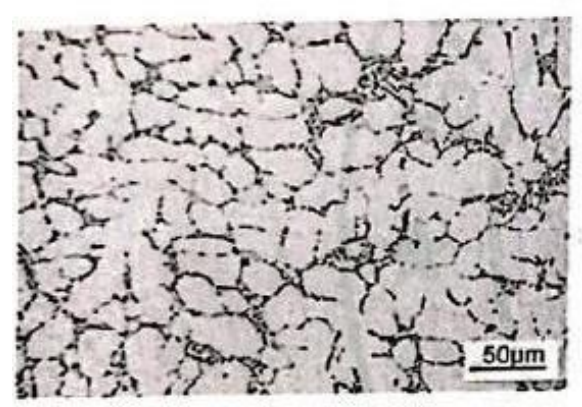

Remark:

The Solidification of alloy continues with the formation of Al-Si eutectic mixture

Aluminium Composite for $12 \%$

Tensile Test Result:

Test Method: ASTM E8M-15a

\begin{tabular}{|c|c|}
\hline \multicolumn{2}{|c|}{ TEST RESULTS } \\
\hline Initial Area $\left(\mathrm{mm}^{2}\right)$ & 65.27 \\
\hline Initial Gauge Length $(\mathrm{mm})$ & 45.00 \\
\hline Final Gauge Length $(\mathrm{mm})$ & 50.11 \\
\hline Yield Strength $(\mathrm{MPa})$ & 231.40 \\
\hline Ultimate Tensile Load $(\mathrm{kN})$ & 17.85 \\
\hline Ultimate Tensile Strength $(\mathrm{MPa})$ & 273.60 \\
\hline$\%$ Elongation & 11.35 \\
\hline
\end{tabular}

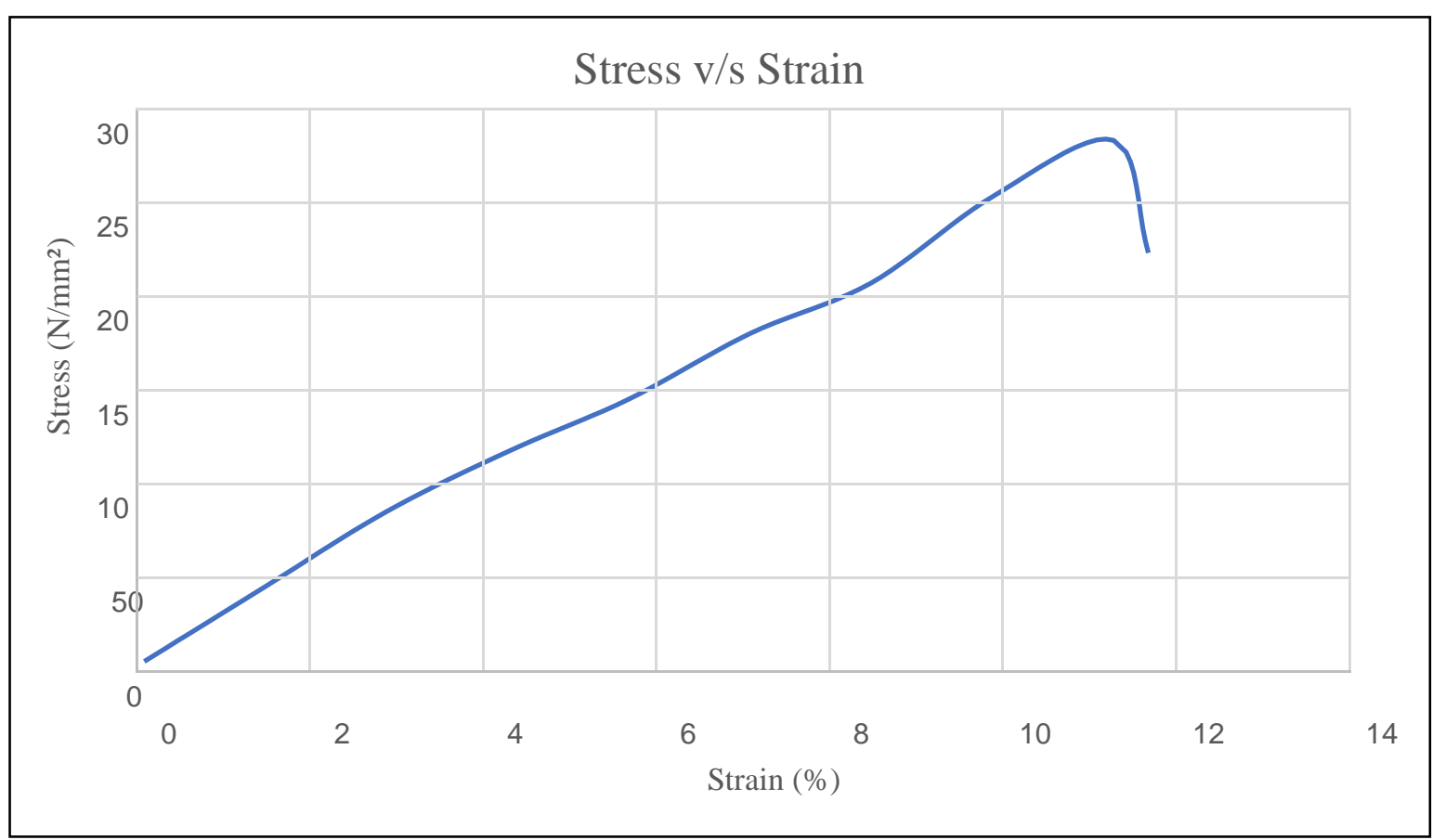


International Advanced Research Journal in Science, Engineering and Technology

Impact Factor $7.105 \div$ Vol. 9, Issue 1, January 2022

DOI: 10.17148/IARJSET.2022.9162

BHN Hardness Test:

Test Method: IS 1500-2010 Ball Dia: 5mm

Load $250 \mathrm{Kg}$

\begin{tabular}{|l|l|l|l|l|}
\hline Sample & Result-1 & Result-2 & Result-3 & Average \\
\hline 01 & 113.6 & 114.2 & 114.8 & 114.2 \\
\hline
\end{tabular}

\section{Compression Test:}

\begin{tabular}{|l|l|l|l|l|}
\hline Sample & Dia $(\mathrm{mm})$ & Area $\left(\mathrm{mm}^{2}\right)$ & Compression Load $(\mathrm{KN})$ & Compression Strength $(\mathrm{MPa})$ \\
\hline 01 & 20.00 & 314.2 & 103.57 & 329.63 \\
\hline
\end{tabular}

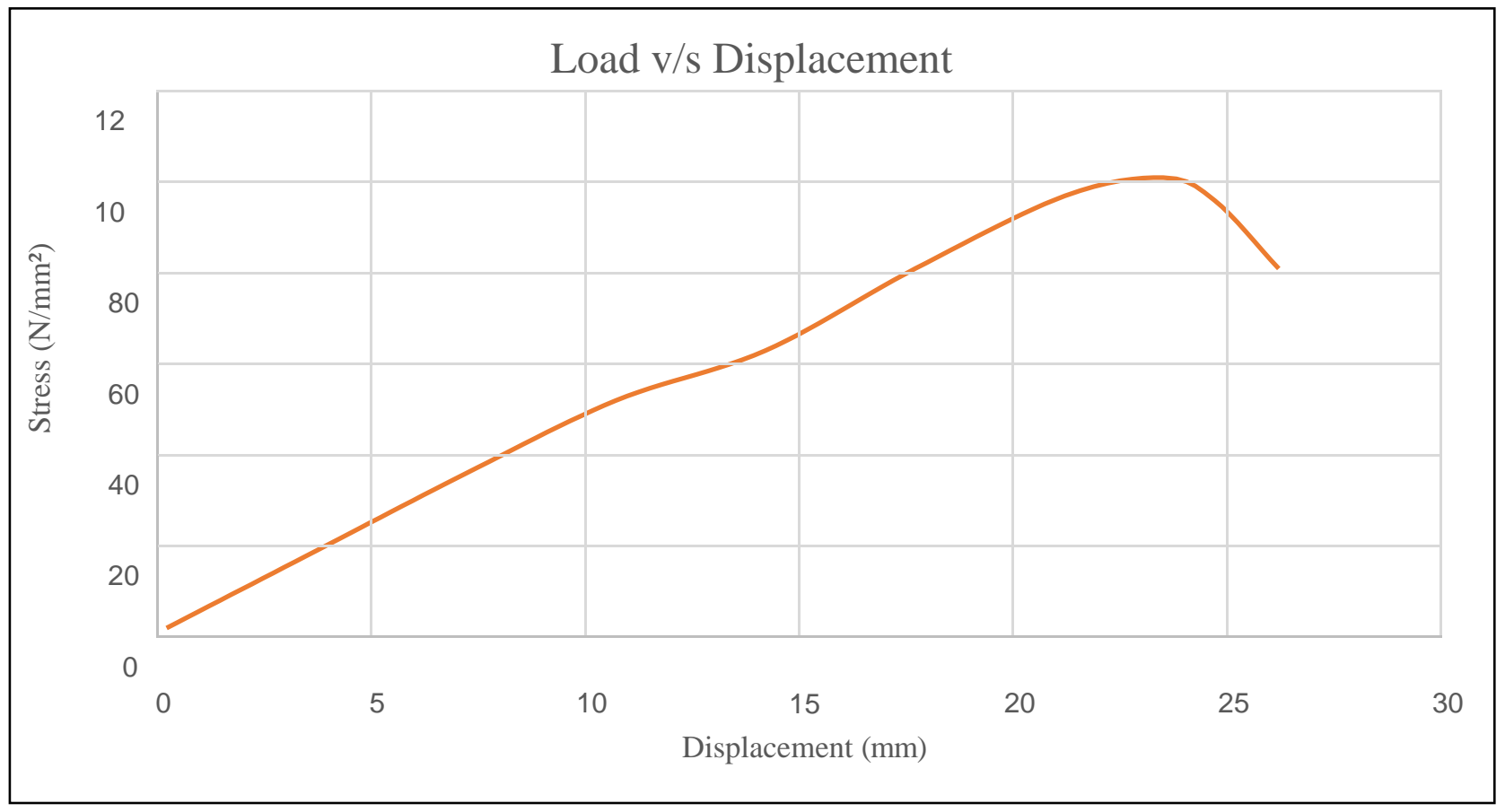

Microstructure Analysis:

Test Method: ASTM A356-19

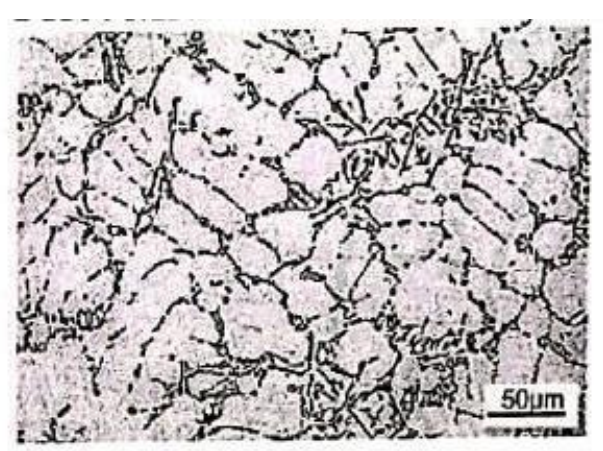

Remark:

The Solidification of alloy continues with the formation of Al-Si eutectic mixture 


\section{International Advanced Research Journal in Science, Engineering and Technology \\ Impact Factor 7.105 ㄷ Vol. 9, Issue 1, January 2022 \\ DOI: 10.17148/IARJSET.2022.9162}

\section{Result Comparison:}

\begin{tabular}{|c|c|c|c|c|}
\hline Material & $\begin{array}{c}\text { Ultimate Tensile } \\
\text { Strength (MPa) }\end{array}$ & $\begin{array}{c}\text { Ultimate Yield } \\
\text { Strength (MPa) }\end{array}$ & Hardness (BHN) & $\begin{array}{c}\text { Compression Strength } \\
\text { (MPa) }\end{array}$ \\
\hline Pure Aluminium & 130 & 95 & 35 & 161.6 \\
\hline $\begin{array}{c}\text { AMC-AV } \\
3 \%\end{array}$ & 199.30 & 168.30 & 76.33 & 247.07 \\
\hline $\begin{array}{c}\text { AMC-AV } \\
6 \%\end{array}$ & 225.30 & 191.40 & 191.36 & 291.97 \\
\hline $\begin{array}{c}\text { AMC-AV } \\
9 \%\end{array}$ & 246.30 & 210.50 & 103.23 & 329.63 \\
\hline $\begin{array}{c}\text { AMC-AV } \\
12 \%\end{array}$ & 273.60 & 231.40 & 114.2 & \\
\hline
\end{tabular}

Table: Comparison of materials

\section{CONCLUSION AND FUTURE SCOPE}

\section{Conclusion:}

From this experimental investigation, the following conclusions were drawn:

Aloe vera (AV) is a less dense, abundantly available, low-cost eco-friendly material that is used in the present work as reinforcement material for preparing aluminium metal matrix composites.

Aluminium metal matrix composite reinforced with aloe vera powder has been successfully fabricated by using the stir casting process.

There was a good dispersibility of AV powder particles in the aluminium matrix which improves the hardness of the matrix material and also the tensile behaviour of the composite.

The Brinell hardness number of AMC-AV is higher than that of pure aluminium.

The reinforcement of aluminium matrix with aloe vera powder increases the ultimate tensile strength by an amount of $53.1 \%, 73.31 \%, 89.46 \%, 110.46 \%$ for $3 \%, 6 \%, 9 \%$ and $12 \%$ respectively. The improvement in ultimate tensile strength using aloe vera powder indicates the suitability of AMC-AV for high strength applications.

\section{Future Scope:}

The fabrication of AMC-AV involves the addition of reinforcement material (aloe vera) in powder form and hence the developed composite is an eco-friendly material.

The AMC-AV can be suitably adopted in various fields such as automotive, aerospace, marine etc.

Similar experimentation can be carried out for different percentages of aloe vera powder.

\section{REFERENCES}

1. K.K.Alaneme, K.O.Sanusi, Microstructural characteristics, mechanical and wear behaviour of aluminium matrix hybrid composites reinforced with alumina, rice husk ash and graphite, Engineering Science and Technology- An International Journal,18(2015), pp. 416-422.

2. A.Dey, K.M.Pandey, Characterization of fly ash and its reinforcement effect on metal matrix composites: A review, Reviews on Advanced Materials Science, 44(2016), pp.168-181.

3. Sudarshan, M.K.Surappa, Synthesis of fly ash particle reinforced A356 AL composites and their characterization, Material Science and Engineering A, 480(2008), pp.117-124.

4. S.G.Kulkarni, J.V.Meghnani, A.Lal, Effect of fly ash hybrid reinforcement on mechanical property and density of Aluminium 356 alloy Procedia Materials Science, 5 ( 2014 ), pp. 746 - 754.

5. D. Siva Prasad, A. Rama Krishna, Fabrication and Characterization of A 356.2 - Rice husk ash composite using stir casting technique, International Journal of Engineering Science and Technology, 2(2010), pp. 7603-7608.

6. K.Manvitha, B.Bidya, Aloe vera: a wonder plant its history, cultivation and medicinal uses, Journal of Pharmacognosy and Phytochemistry, 2(2014), pp. 85-88. 
DOI: 10.17148/IARJSET.2022.9162

7. Nikhilesh Chawla, K.K.Chawla, Metal matrix composites, Springer-Verlag, New York, 2013.

8. Mechanical Characterization of Aluminium Metal Matrix Composite Reinforced with Aloe vera powder; Materials Today: Proceedings 5 (2018) 3289-3297; Ch. Hima Gireesh, K.G.Durga Prasad, K.Ramji, P. V.Vinay.

9. M. Ramachandra, K. Radhakrishna, Effect of reinforcement of fly ash on sliding wear, slurry erosive wear and corrosive behaviour of aluminium matrix composite, Wear, 262(2007), pp. 1450-1462.

10.P.K.Rohatgi, R.Q.Guo, P.Huang, S.Ray, Friction and Abrasion Resistance of Cast Aluminium Alloy-Fly ash Composites, Metallurgical and Materials Transactions A, 28(1997), pp. 245-250.

11. T.Mulu, F.Teshale, S.Gemeda, O.Sahu, Medicated Evaluation of Aloe Vera: Overview on Characteristics and Application, World Journal of Nutrition and Health, 3(2015), pp.1-7. 